\title{
Production and Characterization of Lipases by Two New Isolates of Aspergillus through Solid-State and Submerged Fermentation
}

\author{
Luciane Maria Colla, ${ }^{1}$ Aline M. M. Ficanha, ${ }^{1}$ Juliana Rizzardi, ${ }^{1}$ Telma Elita Bertolin, \\ Christian Oliveira Reinehr, ${ }^{1}$ and Jorge Alberto Vieira Costa ${ }^{2}$ \\ ${ }^{1}$ Laboratory of Fermentations, Food Engineering Course, University of Passo Fundo, Campus I, km 171, BR 285, P.O. Box 611, \\ 99001-970 Passo Fundo, RS, Brazil \\ ${ }^{2}$ Laboratory of Biochemical Engineering, College of Chemistry and Food Engineering, Federal University of Rio Grande do Sul, \\ P.O. Box 474, 96203-900 Rio Grande, RS, Brazil
}

Correspondence should be addressed to Luciane Maria Colla; lmcolla2@gmail.com

Received 11 August 2014; Revised 20 October 2014; Accepted 23 October 2014

Academic Editor: Thean-Hock Tang

\begin{abstract}
Copyright ( 2015 Luciane Maria Colla et al. This is an open access article distributed under the Creative Commons Attribution License, which permits unrestricted use, distribution, and reproduction in any medium, provided the original work is properly cited.

Due to the numerous applications of lipases in industry, there is a need to study their characteristics, because lipases obtained from different sources may present different properties. The aim of this work was to accomplish the partial characterization of lipases obtained through submerged fermentation and solid-state fermentation by two species of Aspergillus. Fungal strains were isolated from a diesel-contaminated soil and selected as good lipases producers. Lipases obtained through submerged fermentation presented optimal activities at $37^{\circ} \mathrm{C}$ and $\mathrm{pH} 7.2$ and those obtained through solid-state fermentation at $35^{\circ} \mathrm{C}$ and $\mathrm{pH} 6.0$. The enzymes produced by submerged fermentation were more temperature-stable than those obtained by solid-state fermentation, presenting $72 \%$ of residual activity after one hour of exposition at $90^{\circ} \mathrm{C}$. Lipases obtained through submerged fermentation had $80 \%$ of stability in acidic $\mathrm{pH}$ and those obtained through solid-state fermentation had stability greater than $60 \%$ in alkaline $\mathrm{pH}$.
\end{abstract}

\section{Introduction}

Lipases (triacylglycerol acyl-hydrolases EC3.1.1.3) are enzymes capable of hydrolyzing the ester bonds of insoluble substrates in water at the substrate-water interface [1]. The main industrial applications of lipases are in detergents [2], medicines [3], and foods [1]. The maturation of cheeses [4], the synthesis of aromas [5], and the production of lipids with high levels of unsaturated fatty acids [6,7] are examples of the application in food industry. The production of methyl-esters of fatty acids (biodiesel) [8] is the most recent and mentioned application nowadays.

As revised by Treichel et al. [9] many researchers worldwide direct their activities to the screening of new lipaseproducing microorganisms and, subsequently, to the optimization of the medium composition and operational variables. All these efforts are justified by the great versatility of lipase applications. Due to the numerous applications of lipases in industry, there is a need to study their characteristics, because lipases obtained from different sources may have different properties [10].

The optimum activity of enzymes depends on the integrity of its structure; therefore factors that may affect these, such as $\mathrm{pH}$, temperature, chemical agents, autolysis (proteases), and ionic strength, affect the enzyme's maximum activity [11]. Temperature has a significant effect on the kinetic energy of enzyme molecules and substrates and causes a greater number of productive collisions per unit of time. The inactivation of enzymatic activity can result from the absorption of excessive energy which causes the disruption or denaturation of the enzyme's tertiary structure due to changes in bonds, such as hydrogen bonds, disulfide bonds, and hydrophobic interactions [12]. The pH affects the stability of enzymes by changing the electrostatic interactions of their protein structure, causing changes in the amino acids' ionization status, which defines the secondary and tertiary structures of protein and therefore its activity and stability $[13,14]$. 
According to Glogauer et al. [15], determination of the $\mathrm{pH}$ stability of enzymes is important for identifying nondenaturing $\mathrm{pH}$ values of buffers for purification, storage, and reaction steps. With regard to temperature, in an enzymatic process there is a critical play between thermostability and the effect of temperature on activity. It is necessary to identify a reaction temperature that at the same time allows a reasonably high rate of reaction and keeps the rate of denaturation at a reasonably low level.

Given the importance of characterizing lipases obtained from new sources in order to determine their application, the aim of this work was to characterize the lipases produced by Aspergillus flavus and Aspergillus niger through submerged and solid-state fermentation, respectively, according to the optimum temperature and $\mathrm{pH}$, and to determine the stability of enzymes in relation to temperature and $\mathrm{pH}$.

\section{Material and Methods}

2.1. Microorganisms: Isolation, Maintenance, and Inoculum Preparation. The filamentous fungi Aspergillus (strain O8) and Aspergillus (strain O-4) were isolated from dieselcontaminated soil and previously selected as a good producer of lipase through submerged [16] and solid-state fermentation [17], respectively. The contaminated soil was collected after a case of leaking diesel from a storage tank to the fuel station, which occurred in the city of Passo Fundo, RS, Brazil.

The isolates were submitted to genetic identification through Phred/Phrap and Consed, using the methodology cited by Smaniotto et al. [18], at the Center of Nuclear Energy in Agriculture (Cena) from University of São Paulo (USP), Brazil. Sequences were compared to $18 \mathrm{~S}$ rRNA data obtained from GenBank (http://www.ncbi.nlm.nih.gov/).

The isolate O-8 was identified as Aspergillus flavus strain DAOM (99\% identity, GenBank accession number: JN938987.1) and the isolate O-4 was identified as Aspergillus niger DAOM (100\% identity, GenBank accession number: KC545858.1).

After isolation, the microorganisms were kept in tubes with potato dextrose agar (PDA) inclined under $4^{\circ} \mathrm{C}$ refrigeration, with periodic replications every 3 months.

The inoculum preparation of Aspergillus flavus to submerged fermentation was carried out by inoculation of the fungi in Petri dishes with $30 \mathrm{~mL}$ of solidified PDA and incubation at $30^{\circ} \mathrm{C}$ for 5 days. The inoculation was accomplished using $10 \mathrm{~mm}$ of diameter circular areas containing spores growth prepared in Petri dishes [19].

The inoculum preparation of Aspergillus niger to solidstate fermentation was carried out by inoculating the fungus in $1 \mathrm{~L}$ Erlenmeyer's flasks containing $30 \mathrm{~mL}$ of solidified PDA medium and incubated at $30^{\circ} \mathrm{C}$ for 5 days. A spore suspension was obtained by adding $20 \mathrm{~mL}$ of a $0.1 \%$ Tween to the inoculum after incubation and by scraping the spores with a Drigalski loop. The fermentation media were inoculated with $2.10^{6}$ spores/g [19].

2.2. Culture Medium to Solid-State and Submerged Fermentation. The culture conditions of lipase production in submerged and solid-state fermentation had been previously optimized [19].

The medium to submerged fermentation was prepared with $10 \%(\mathrm{w} / \mathrm{v})$ of wheat bran, which was boiled at $100^{\circ} \mathrm{C}$ for $30 \mathrm{~min}$. Afterwards, the medium was filtered and the soluble extract added to $10 \%(\mathrm{v} / \mathrm{v})$ of saline solution, $45 \mathrm{~g} / \mathrm{L}$ of yeast extract as nitrogen source and $20 \mathrm{~g} / \mathrm{L}$ of soybean oil as inducer. The composition of saline solution [20] was $2 \mathrm{~g} / \mathrm{L} \mathrm{KH}_{2} \mathrm{PO}_{4}, 1 \mathrm{~g} / \mathrm{L} \mathrm{MgSO}_{4}$, and $10 \mathrm{~mL} / \mathrm{L}$ of trace solution containing (mg/L) FeSO $\cdot 7 \mathrm{H}_{2} \mathrm{O}(0.63), \mathrm{MnSO}_{4}(0.01), \mathrm{ZnSO}_{4}$ (0.62). The medium was autoclaved at $103 \mathrm{kPa}$ for $20 \mathrm{~min}$ and the $\mathrm{pH}$ adjusted to 7.0 using $\mathrm{HCl} 1.5 \mathrm{~mol} / \mathrm{L}$ or $\mathrm{NaOH} 1 \mathrm{~mol} / \mathrm{L}$. After inoculation, the cultures were incubated for 4 days at $30^{\circ} \mathrm{C}$ with agitation of $160 \mathrm{~min}^{-1}$.

The medium for solid-state fermentation was prepared under previously optimized conditions [20] with $85 \%$ of soybean or wheat bran and $15 \%$ of rice husk. The medium was added to $71 \%(\mathrm{v} / \mathrm{w})$ of saline solution [20] and $2 \%$ of sodium nitrate as nitrogen source. The medium was autoclaved at $103 \mathrm{kPa}$ for $20 \mathrm{~min}$ and subsequently added to $2 \%$ olive oil as an inducer of lipase production. The $\mathrm{pH}$ was adjusted to 4.5 by the addition of a $1.5 \mathrm{~mol} / \mathrm{L}$ solution of $\mathrm{H}_{2} \mathrm{SO}_{4}$ and moisture was adjusted to $60 \%$ by adding sterile distilled water. Fermentations were carried out in $300 \mathrm{~mL}$ Erlenmeyer's flasks containing $50 \mathrm{~g}$ of the medium, which were incubated at $30^{\circ} \mathrm{C}$ for $96 \mathrm{~h}$ after inoculation. The fermented brans were kept at $-20^{\circ} \mathrm{C}$ until use.

2.3. Achievement of Enzymatic Extracts. After the production of lipase by submerged and solid-state fermentation, procedures for obtaining the enzymatic extracts were conducted, which are described below.

The fermented medium obtained under submerged fermentation by the fungi Aspergillus flavus was filtered in cotton for the retention of hyphae and frozen at $-20^{\circ} \mathrm{C}$, being after used in the determinations of enzymatic activities [19].

The extraction of lipase from the fermented bran obtained in solid-state fermentation by the fungi Aspergillus niger was carried out by adding $10 \mathrm{~mL}$ buffer with $\mathrm{pH}$ established in each methodology at $1 \mathrm{~g}$ of fermented medium, followed by agitation of $160 \mathrm{~min}^{-1}$ for $30 \mathrm{~min}$ at $37^{\circ} \mathrm{C}$. The extract was cotton-filtered and used as enzyme extract in subsequent reactions [19].

\subsection{Effect of $p H$ and Temperature on the Optimal Activity of} Enzymatic Extracts. The enzymatic extracts without the cells of microorganisms were submitted to tests to determine the influence of $\mathrm{pH}$ and temperature on the enzymatic activities.

The optimum activity of enzymatic extracts produced through submerged fermentation was determined by a Central Composite Design (CCD) composed of 4 factorial points, 4 axial points, and 3 central points (Table 1). The levels of variables ranged from $28^{\circ} \mathrm{C}$ to $42^{\circ} \mathrm{C}$ for temperature and 6.3 to 7.7 for $\mathrm{pH}$. Optimum $\mathrm{pH}$ and temperature for activity of the enzymes produced through solid-state fermentation were determined using a $3^{2}$ Full Factorial Design (FFD) (Table 2). The variables levels were 5 to 7 for the $\mathrm{pH}$ and $30^{\circ} \mathrm{C}$ to $40^{\circ} \mathrm{C}$ for the temperature. 
TABLE 1: Central composite design (CCD) used to determine the influence of $\mathrm{pH}$ and temperature on the optimal activity of lipase obtained through submerged fermentation by Aspergillus flavus (strain O-8) and results of lipolytic activity $(\mathrm{U} / \mathrm{mL})$. Results of mean and standard deviation.

\begin{tabular}{lccc}
\hline Experiment & $\mathrm{pH}\left(X_{1}\right)^{*}$ & Temperature $\left(X_{2}\right)$ & $\begin{array}{c}\text { Lipolytic } \\
\text { activity }(\mathrm{U} / \mathrm{mL})\end{array}$ \\
\hline 1 & $6.5(-1)$ & $30^{\circ} \mathrm{C}(-1)$ & $3.15 \pm 0.13$ \\
2 & $7.5(+1)$ & $30^{\circ} \mathrm{C}(-1)$ & $3.72 \pm 0.01$ \\
3 & $6.5(-1)$ & $40^{\circ} \mathrm{C}(+1)$ & $3.21 \pm 0.07$ \\
4 & $7.5(+1)$ & $40^{\circ} \mathrm{C}(+1)$ & $4.02 \pm 0.08$ \\
5 & $6.3(-1.414)$ & $35^{\circ} \mathrm{C}(0)$ & $3.54 \pm 0.05$ \\
6 & $7.7(+1.414)$ & $35^{\circ} \mathrm{C}(0)$ & $4.23 \pm 0.02$ \\
7 & $7.0(0)$ & $28^{\circ} \mathrm{C}(-1.414)$ & $3.82 \pm 0.01$ \\
8 & $7.0(0)$ & $42^{\circ} \mathrm{C}(+1.414)$ & $4.37 \pm 0.03$ \\
9 & $7.0(0)$ & $35^{\circ} \mathrm{C}(0)$ & $4.30 \pm 0.12$ \\
10 & $7.0(0)$ & $35^{\circ} \mathrm{C}(0)$ & $4.26 \pm 0.01$ \\
11 & $7.0(0)$ & $35^{\circ} \mathrm{C}(0)$ & $4.03 \pm 0.03$ \\
\hline
\end{tabular}

${ }^{*}$ Conditions of $\mathrm{pH}$ obtained using $0.2 \mathrm{M}$ phosphate buffer in the enzymatic activity determination.

TABLE 2: Full Factorial Design $\left(3^{2}\right)$ used to determine the influence of $\mathrm{pH}$ and temperature on optimum activity of lipase obtained through solid-state fermentation by Aspergillus niger (strain O-4) and results of lipolytic activity (U/g). Results of mean and standard deviation.

\begin{tabular}{lccc}
\hline Experiment & $\mathrm{pH}\left(X_{1}\right)^{*}$ & $\begin{array}{c}\text { Temperature } \\
\left({ }^{\circ} \mathrm{C}\right)\left(X_{2}\right)\end{array}$ & $\begin{array}{c}\text { Lipolytic } \\
\text { activity }(\mathrm{U} / \mathrm{g})\end{array}$ \\
\hline 1 & $5(-1)$ & $30(-1)$ & $12.20 \pm 0.96$ \\
2 & $6(0)$ & $30(-1)$ & $40.62 \pm 1.90$ \\
3 & $7(+1)$ & $30(-1)$ & $15.49 \pm 1.92$ \\
4 & $5(-1)$ & $35(0)$ & $34.14 \pm 2.52$ \\
5 & $6(0)$ & $35(0)$ & $42.82 \pm 1.65$ \\
6 & $7(+1)$ & $35(0)$ & $35.41 \pm 1.92$ \\
7 & $5(-1)$ & $40(+1)$ & $10.53 \pm 0.96$ \\
8 & $6(0)$ & $40(+1)$ & $34.58 \pm 1.65$ \\
9 & $7(+1)$ & $40(+1)$ & $22.13 \pm 0.96$ \\
\hline
\end{tabular}

${ }^{*}$ Conditions of $\mathrm{pH}$ obtained using $0.2 \mathrm{M}$ phosphate buffer in the steps of enzyme extraction of the fermented bran and in the enzymatic activity determination.

The enzyme activity was determined using the method standardized by Burkert et al. [21] which is based on titration with $\mathrm{NaOH}$ of fatty acids released by the action of lipase in the extract on the triacylglycerols of olive oil emulsified in arabic gum. The following were added to $250 \mathrm{~mL}$ flasks: $2 \mathrm{~mL}$ buffer prepared according to the objective of the test, $5 \mathrm{~mL}$ of emulsion prepared with $75 \mathrm{~mL}$ of $7 \%$ arabic gum, and $25 \mathrm{~mL}$ of olive oil. Next, $1 \mathrm{~mL}$ of enzyme extract was added to this system and it was incubated at temperatures described in the experimental design for $30 \mathrm{~min}$. After incubation, the reaction was stopped by adding $15 \mathrm{~mL}$ of acetone: ethanol: water $(1: 1: 1)$ and the released fatty acids were titrated with a solution of $0.01 \mathrm{~mol} / \mathrm{L} \mathrm{NaOH}$ using phenolphthalein as indicator. One unit of activity was defined as the amount of enzyme that releases $1 \mu \mathrm{mol}$ of fatty acid per minute per $\mathrm{mL}$ of enzyme extract of submerged fermentation $(1 \mathrm{U}=1 \mu \mathrm{mol} / \mathrm{min} \cdot \mathrm{mL})$ or per $\mathrm{g}$ of fermented brand ( $1 \mathrm{U}$ $=1 \mu \mathrm{mol} / \mathrm{min} \cdot \mathrm{g}$ ) of solid-state fermentation, under the test conditions.

2.5. Temperature Stability of Enzymatic Extracts. Thermostability of lipases obtained through submerged and solid-state fermentation was measured by incubating the enzyme extract at $35^{\circ} \mathrm{C}$ to $90^{\circ} \mathrm{C}$. Aliquots were periodically taken to measure lipolytic activity, using the optimum temperature and $\mathrm{pH}$ for enzyme activity, obtained as mentioned in Section 2.4, to each enzymatic extract. The experiments were duplicated.

For the enzymes obtained through solid-state fermentation it was possible to calculate the Arrhenius thermal deactivation and activation energy for thermal destruction constants $\left(E_{a}\right)$. Therefore, the data of enzymatic activity at each temperature tested were used to calculate the residual lipase activity $(R A)$ over time. The constant of thermal deactivation $\left(k_{d}\right)$ at each temperature was calculated by linear regression of the data of $\operatorname{Ln}(R A)$ versus time, according to the Arrhenius kinetic model, considering that inactivation of the enzyme obeys first-order kinetics, as in the following. Consider

$$
\frac{d[E]}{[E]}=-k_{d} \cdot d t
$$

After integration,

$$
\operatorname{Ln} \frac{[E]_{2}}{[E]_{1}}=-k_{d} \cdot \Delta t .
$$

Considering that the enzyme concentration $([E])$ is directly proportional to the enzymatic reaction speed,

$$
\frac{[E]_{2}}{[E]_{1}}=A R .
$$

We get the following:

$$
\operatorname{Ln}(A R)=-k_{d} \cdot \Delta t .
$$

From the thermal deactivation constants at each temperature, the half-lives $\left(t_{1 / 2}\right)$ were obtained (5) which corresponds to the time required, at the temperature tested, so that $50 \%$ of the initial enzyme concentration is inactivated:

$$
t_{1 / 2}=\frac{0.693}{k_{d}} .
$$

The activation energy $\left(E_{a}\right)$ for thermal destruction of the enzyme was calculated from (6). The value of $E_{a}$ was obtained from the inclination of the regression line of $\ln K$ versus $1 / T$ :

$$
\ln K=\ln A-\frac{E_{a}}{R T},
$$

where $[E]=$ enzyme concentration, $A R=$ residual activity of the enzyme, $t=$ time $(\mathrm{min}), k_{d}=$ thermal deactivation constant, $A=$ Arrhenius factor (depending, among other things, on the contact area), $E_{a}=$ activation energy, $R=$ ideal gases constant $\left(8.314 \mathrm{~J} \mathrm{~mol}^{-1} \mathrm{~K}^{-1}\right)$, and $T=$ absolute temperature (K). 
2.6. $p H$ Stability of Enzymatic Extracts. The effect of $\mathrm{pH}$ on the stability of enzymes obtained through submerged fermentation was determined by treating $1 \mathrm{~mL}$ of enzyme extract with $2 \mathrm{~mL}$ of buffer solutions at $\mathrm{pH} 3.5,4.0,4.5,5.0$, $5.5,6.0,6.5,7.0,8.0$, and 9.0 for 24 hours at $25^{\circ} \mathrm{C}$. The buffers used were $0.1 \mathrm{~mol} / \mathrm{L}$ citrate $(\mathrm{pH} 3.5), 0.2 \mathrm{~mol} / \mathrm{L}$ acetate $(\mathrm{pH} 4.0$ to 5.5$), 0.2 \mathrm{~mol} / \mathrm{L}$ phosphate ( $\mathrm{pH} 6.0$ to 8.0 ), and $0.2 \mathrm{~mol} / \mathrm{L}$ glycine (pH 9 and 10). Enzyme activity in initial and final times was carried out at optimum temperature and $\mathrm{pH}$ for enzyme activity, obtained from the results of the assays of Section 2.4. The experiments were duplicated.

The stability of enzymes obtained through solid-state fermentation was assessed through their extraction from the fermented medium using the following buffer solutions: $0.1 \mathrm{~mol} / \mathrm{L}$ citrate $(\mathrm{pH} 3.5), 0.2 \mathrm{~mol} / \mathrm{L}$ acetate $(\mathrm{pH} 4.0,4.5$, 5.0, and 5.5), $0.2 \mathrm{~mol} / \mathrm{L}$ phosphate ( $\mathrm{pH} 6.0,6.5,7.0,7.5$, and 8.0 ), and $0.2 \mathrm{~mol} / \mathrm{L}$ glycine ( $\mathrm{pH} 9$ and 10 ). The extracts were kept at $25^{\circ} \mathrm{C}$ for $24 \mathrm{~h}$ and the residual lipolytic activity was determined at optimum temperature and $\mathrm{pH}$ for enzyme activity, according to the results obtained from the assays of Section 2.4.

\section{Results and Discussion}

In the submerged culture fermentation the microorganisms grow in a liquid medium in which the nutrients are dissolved. In solid-state fermentation the microorganisms grow on the surface of a solid matrix in which the nutrients are adsorbed, and the moisture does not exceed the water retention capacity of this matrix $[22,23]$. These differences between production methods as well as the differences between the microorganisms used in fermentation processes can lead to obtaining lipases with different characteristics.

3.1. Effect of $p H$ and Temperature on the Optimal Activity of Enzymatic Extracts. The $\mathrm{pH}$ and temperature have great influence on the enzyme activity, being important to define these parameters for the characterization of the enzymes obtained. After fungal growth in culture media of submerged and solid-state fermentations, enzymatic extracts were obtained as described in Section 2.3 and used in the assays mentioned in Section 2.4. The results of enzymatic activities were presented in Tables 1 and 2, which also shows the experimental conditions of the experimental designs used to determine optimum temperatures and $\mathrm{pH}$ of the enzymes produced through submerged and solid-state fermentations, respectively.

The highest lipolytic activities in the solid-state fermentation (Table 2) may be due to the characteristics of this type of cultivation when compared with submerged cultivation. In the solid state fermentation, the concentration of the final product is higher and the fungus has the appropriate characteristics, as tolerance to low water activity and production of enzymes through hyphae [23]. Furthermore, lipase production was performed by different microorganisms, although both are of the genus Aspergillus.

The analysis of variance of lipolytic activity obtained in each experimental design demonstrated, that in both cases, the $F_{\text {calculated }}$ obtained in the analysis of regression models were higher than the $F_{\text {tabulated }}$ value $\left(F_{\text {calculated }}\right.$ of 6.43 and $F_{\text {tabulated }}$ of 2.85 for Composite Central Design of submerged fermentation; $F_{\text {calculated }}$ of 32.2 and $F_{\text {tabulated }}$ of 2.80 for Full Factorial Design of solid-state fermentation), which means that the variation caused by the models is significantly greater than the unexplained variation [24].

Equations (7) and (8) show the regression models for the enzymes obtained through submerged fermentation (SmF) and solid-state fermentation (SSF), respectively. The correlation coefficients between experimental data and models were of $81.7 \%$ and $94.02 \%$, which validates the mathematical models obtained $[25,26]$ :

$$
\begin{aligned}
\mathrm{AL}_{\mathrm{SmF}}= & 4.19+0.28 \cdot X_{1}-0.254 \cdot X_{1}{ }^{2}+0.142 \cdot X_{2} \\
& -0.17 \cdot X_{2}{ }^{2}, \\
\mathrm{AL}_{\mathrm{SSF}} & =49.2+2.7 \cdot X_{1}-17.7 \cdot X_{1}{ }^{2}-14.9 \cdot X_{2}{ }^{2} .
\end{aligned}
$$

The estimated effects of variables of CCD on lipolytic activity showed that linear and quadratic effects of $\mathrm{pH}$ were significant $(P<0.05)$. The temperature had significance levels very close to 0.05 , of $P=0.057$ and $P=0.054$, for the linear and quadratic effects, respectively. Thus, the effect of temperature was considered for the expression of the model. Both variables showed positive linear effects, and the effect of $\mathrm{pH}$ was greater than the effect of temperature (0.561 and 0.284 , resp.).

Linear and quadratic effects of $\mathrm{pH}$ were significant $(P=$ 0.02 and $P<0.01$, resp.) and positive on the activity of lipases obtained through solid-state fermentation (5.4 and -35.4 , resp.). On the other hand, only the quadratic effect of temperature $(-29.7)$ had significant influence $(<0.01)$ on the lipolytic activity.

The use of response surface methodology has the advantage of allowing the estimation of the effects of experimental variables on the response variable within the limits stipulated by the experimental design. Thus, the optimal values of the experimental variables can be calculated from the mathematical modeling of the data, when the response surface is validated by analysis of variance. The optimal $\mathrm{pH}$ and temperature were calculated by equating the first derivative of the lipolytic activity as a function of the $\mathrm{pH}$ and temperature to zero in both mathematical models. The maximum lipolytic activities of lipases obtained through submerged fermentation were obtained at the levels +0.55 and +0.417 from $\mathrm{pH}$ and temperature, respectively, corresponding to $\mathrm{pH} 7.2$ and temperature of $37^{\circ} \mathrm{C}$. The maximum lipolytic activities of lipases obtained through solid-state fermentation were obtained at the levels +0.076 and zero (0) to $\mathrm{pH}$ and temperature, respectively, corresponding to $\mathrm{pH} 6.0$ and temperature of $35^{\circ} \mathrm{C}$. These results could differ a little from the maximum results obtained in Tables 1 and 2, because they were obtained from the mathematical models generated from the experimental data.

Figures 1(a) and 1(b) show the response surface representing the mathematical models of (7) and (8) of the enzymes obtained through submerged and solid-state fermentation, respectively. 


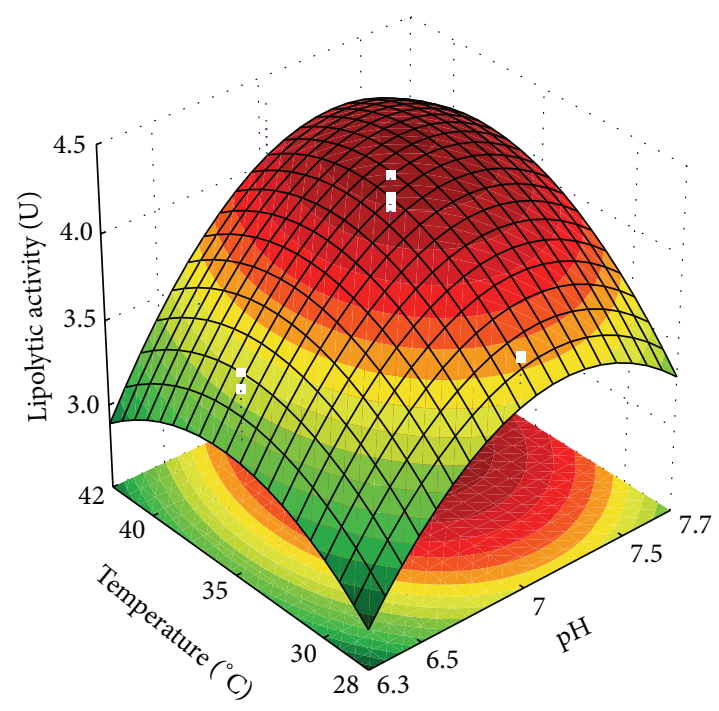

(a)



(b)

FIGURE 1: Response surface of the influence of $\mathrm{pH}$ and temperature on the lipolytic activity of enzymes produced (a) through submerged fermentation by Aspergillus flavus (strain O-8) from CCD and (b) through solid-state fermentation by Aspergillus niger (strain O-4) from the $3^{2}$ Full Factorial Design.

The optimum $\mathrm{pH}$ and temperature found in this study for the activity of fungal lipases are similar to results reported in academic literature, in which maximum lipase activities were obtained at around $30^{\circ} \mathrm{C}$ and $40^{\circ} \mathrm{C}$ and $\mathrm{pH} 6.0$ to 8.0 [27].

Maldonado [10] obtained maximum lipolytic activities at $\mathrm{pH} 7.0$ and $37^{\circ} \mathrm{C}$ for crude and purified lipase of Geotrichum candidum. Baron et al. [28] found that there is a $\mathrm{pH}$ range (6.0 and 8.0) where enzyme activity is maximal and that the activity depends not only on the $\mathrm{pH}$ of the medium but also on the type of buffer used. Freire et al. [29] reported that the optimum $\mathrm{pH}$ and temperature for lipases produced by Penicillium sp. were 7.0 and $37^{\circ} \mathrm{C}$. Benjamin and Pandey [30] reported that the lipases produced by Candida rugosa showed optimum activity at $\mathrm{pH} 7.0$ and temperature $40^{\circ} \mathrm{C}$. Pastore et al. [31] characterized the lipases produced by Rhizopus sp. and found maximum activity at $\mathrm{pH} 6.0$ and 6.5 and $40^{\circ} \mathrm{C}$. However, Diaz et al. [32] characterized the lipases of the fungus Rhizopus homothallicus obtained by solid-state and submerged bioprocesses, obtaining maximum activity at $\mathrm{pH}$ 7.5 and 30 to $40^{\circ} \mathrm{C}$, respectively.

Santos et al. [33] and Lotrakul and Dharmsthiti [34] characterized lipases that obtained maximum activities at temperatures higher than those obtained in this study: $45^{\circ} \mathrm{C}$ to $50^{\circ} \mathrm{C}$ for the lipase produced in solid-state fermentation by Trichosporon spp., and $45^{\circ} \mathrm{C}$ for the lipase from Aeromonas sobria isolated from raw milk, respectively. Shangguan et al. [35] studied a lipase obtained from A. fumigatus that presented optimum $\mathrm{pH}$ and temperature of 8.5 and $65^{\circ} \mathrm{C}$, respectively.

3.2. Temperature Stability. These experiments were conducted to evaluate the stability of enzymes obtained through two fermentation processes. After maintenance of enzymatic extracts at temperatures ranging from $35^{\circ} \mathrm{C}$ to $90^{\circ} \mathrm{C}$ for different periods of time (Section 2.5), the enzymatic activity was evaluated at $\mathrm{pH}$ and temperatures optimized in the previous step (Section 2.4) to each fermentation process.

The temperature stability of lipases produced through submerged fermentation by Aspergillus flavus was initially assessed at 40 to $80^{\circ} \mathrm{C}$, as shown in Figure 2(a). The enzymes were stable between $40^{\circ} \mathrm{C}$ and $50^{\circ} \mathrm{C}$, with residual activity greater than $90 \%$ for 7 hours. An initial inactivation of the enzymes between $70^{\circ} \mathrm{C}$ and $80^{\circ} \mathrm{C}$ was observed and subsequently they became stable, with residual activity of $80 \%$ and $65 \%$ at $80^{\circ} \mathrm{C}$ and $70^{\circ} \mathrm{C}$, respectively. The enzymes did not exhibit first-order thermal destruction kinetic behavior (Arrhenius), despite being more stable at $80^{\circ} \mathrm{C}$ than $70^{\circ} \mathrm{C}$.

In order to confirm the data obtained, tests were carried out at $70^{\circ} \mathrm{C}, 80^{\circ} \mathrm{C}$, and $90^{\circ} \mathrm{C}$ for $8 \mathrm{~h}$, and the results (shown in Figure 2(b)) confirm the aforementioned behavior, with an initial enzyme inactivation, caused by thermal shock, and later stability. Furthermore, the enzymes exhibited greater stability at higher temperatures in the first hour of testing. The lipases were stable at $70^{\circ} \mathrm{C}$ to $90^{\circ} \mathrm{C}$, with mean residual activities of around $72 \%$ after the first hour of incubation.

Figure 3(a) shows the thermal destruction kinetics of the enzyme produced through solid-state fermentation between $35^{\circ} \mathrm{C}$ and $90^{\circ} \mathrm{C}$, which follows the pattern of first-order thermal destruction predicted by the Arrhenius model. Table 3 shows the thermal deactivation constants between $35^{\circ} \mathrm{C}$ and $90^{\circ} \mathrm{C}$, obtained from angular coefficients of the curves shown in Figure 3, as well as the determination coefficients of regression and the half-life of enzymes at each temperature. The enzyme had higher thermal stability at $35^{\circ} \mathrm{C}$ and $40^{\circ} \mathrm{C}$, which can be observed from the high halflives $\left(t_{1 / 2}\right)$, around 6 and $4.3 \mathrm{~h}$, respectively. Above $50^{\circ} \mathrm{C}$, the half-life considerably decreased to $29 \mathrm{~min}$ between $60^{\circ} \mathrm{C}$ and $70^{\circ} \mathrm{C}$. Figure 3(b) shows the graph of $\ln \left(k_{d}\right)$ as a function 


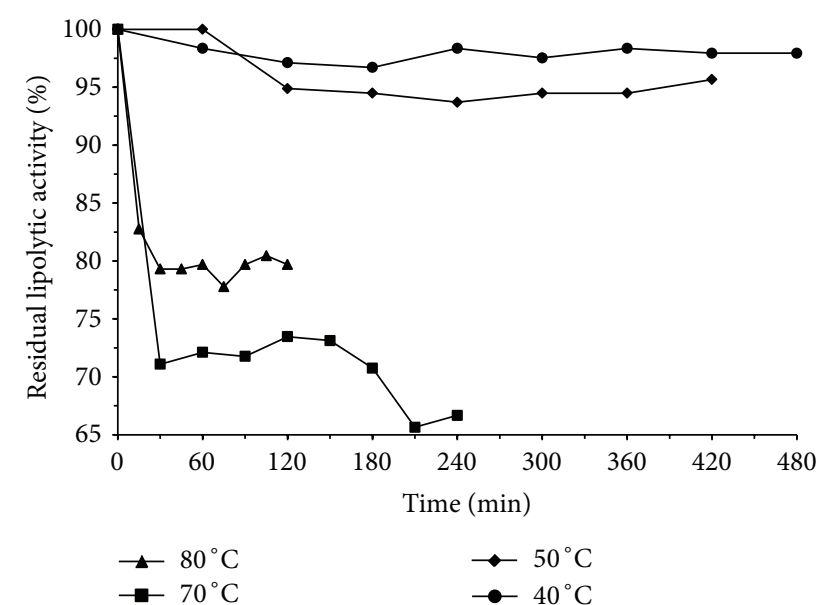

(a)



(b)

FIgURE 2: Thermal stability of lipases produced in submerged fermentation using Aspergillus flavus (strain O-8): (a) $40^{\circ} \mathrm{C}, 50^{\circ} \mathrm{C}$, $70^{\circ} \mathrm{C}$, and $80^{\circ} \mathrm{C}$; (b) $70^{\circ} \mathrm{C}, 80^{\circ} \mathrm{C}$, and $90^{\circ} \mathrm{C}$.

TABLE 3: Thermal deactivation constant $\left(k_{d}\right)$, correlation coefficients of regressions $\left(R^{2}\right)$, and times of half-lives $\left(t_{1 / 2}\right)$ of enzymatic extracts of solid-state fermentation at temperatures of $35^{\circ} \mathrm{C}$ to $90^{\circ} \mathrm{C}$.

\begin{tabular}{lccc}
\hline Temperature $\left({ }^{\circ} \mathrm{C}\right)$ & $k_{d}\left(\mathrm{~min}^{-1}\right)$ & $R^{2}$ & $t_{1 / 2}(\mathrm{~min})$ \\
\hline 35 & 0.0019 & 0.985 & 364.74 \\
40 & 0.0027 & 0.954 & 256.67 \\
50 & 0.0100 & 0.966 & 69.30 \\
60 & 0.0234 & 0.976 & 29.62 \\
70 & 0.0233 & 0.971 & 29.74 \\
80 & 0.0516 & 0.991 & 13.43 \\
90 & 0.0630 & 0.968 & 11.00 \\
\hline
\end{tabular}

of absolute temperature $(\mathrm{K})$, used to calculate the energy of thermal deactivation, which was $60.33 \mathrm{~kJ} / \mathrm{mol}$ for the studied enzyme.

Lipase obtained with solid-state fermentation showed higher energy of deactivation than those obtained by Diaz et

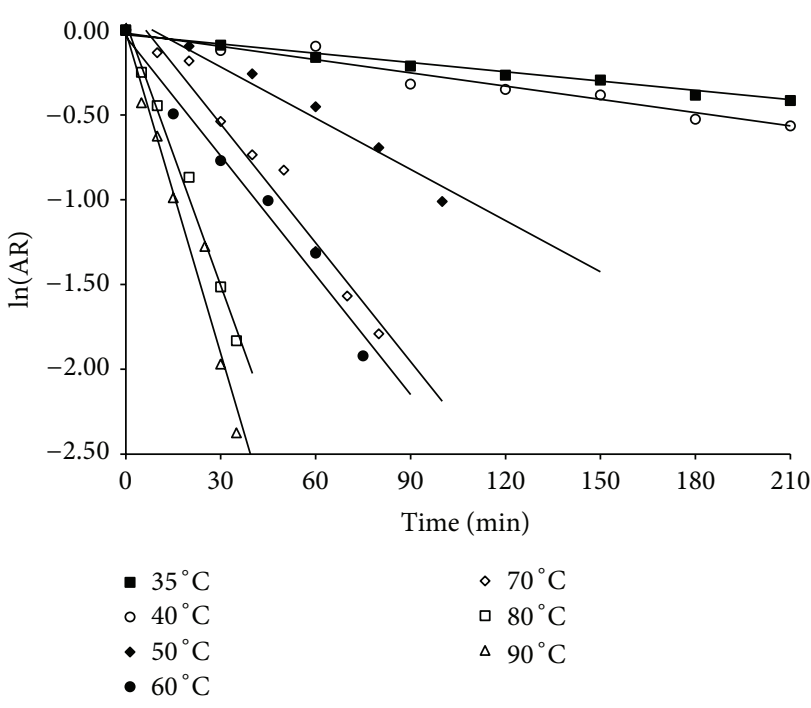

(a)

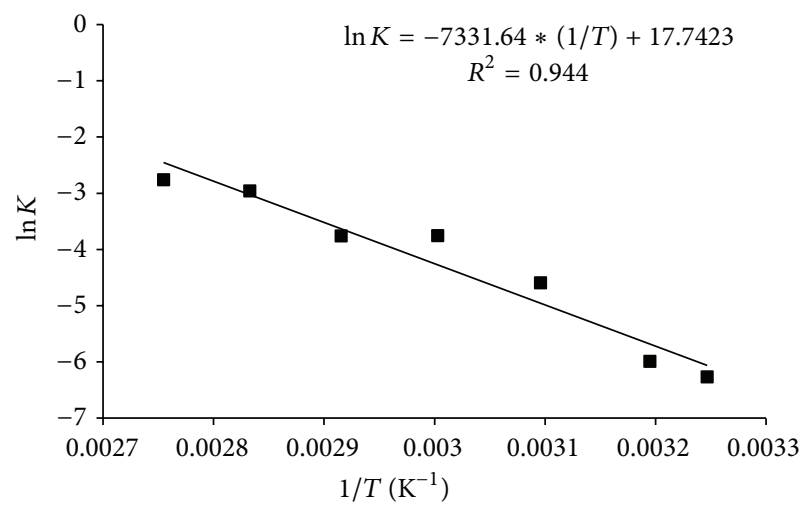

(b)

FIgURE 3: Kinetics of thermal destruction of the enzymatic extracts produced by Aspergillus niger in solid-state fermentation: (a) at temperatures of $35^{\circ} \mathrm{C}$ to $90^{\circ} \mathrm{C}$. AR: enzyme residual activity, (b) linear regression of the thermal deactivation constants obtained at $35^{\circ} \mathrm{C}$ to $90^{\circ} \mathrm{C}$ (ln of data) as function of inverse of absolute temperature for calculating the energy of thermal deactivation of the enzyme.

al. [32] and Lima et al. [36], which were 30 and $34.2 \mathrm{~kJ} / \mathrm{mol}$ for the lipases produced by Rhizopus homothallicus and Bacillus megaterium, respectively. However, they had lower deactivation energy than the ones obtained by Maldonado [10], which were 330,140 , and $182 \mathrm{~kJ} / \mathrm{mol}$ for the lipases produced by Geotrichum candidum in media containing peptone, hydrolyzed yeast, and macerated clarified corn water, respectively. The activation energy reflects the dependence of the thermal deactivation constant with respect to temperature [37, 38], and the higher the constant, the greater the variation of the thermal deactivation constant with the temperature variation.

Razak et al. [39] reported that fungal lipases in general are unstable above $40^{\circ} \mathrm{C}$, with moderate stability, contrary to what has been observed in lipases produced by bacteria such as Bacillus [40,41] and Pseudomonas [42], which are 
thermostable above $60 \mathrm{C}$. However, the lipases produced by Rhizopus sp. maintained $50 \%$ or more of their activity when heated for $60 \mathrm{~min}$ between 40 and $55^{\circ} \mathrm{C}$ [31] and lipases produced by Geotrichum-like R59 showed thermostability, with maximum residual activity after incubation at $60^{\circ} \mathrm{C}$ for $1 \mathrm{~h}[43]$.

Shu et al. [44] reported that the lipases produced by Antrodia cinnamomea had 50\% residual activity between $25^{\circ} \mathrm{C}$ and $40^{\circ} \mathrm{C}$. Lipase from Aspergillus niger NCIM 1207 was stable at $40^{\circ} \mathrm{C}$ for $3 \mathrm{~h}$; however the treatment at $50^{\circ} \mathrm{C}$ for $1 \mathrm{~h}$ caused 52\% loss of activity [45]. Baron et al. [28] showed that the lipases produced by Penicillium corylophilum were completely inactivated after $30 \mathrm{~min}$ at $60^{\circ} \mathrm{C}$. However, the lipases produced by Rhizopus sp. had moderate thermostability, with $70 \%$ residual activity at temperatures of 40 to $55^{\circ} \mathrm{C}$ [31]. Ginalska et al. [43] showed that the lipases produced by Geotrichum sp. had $100 \%$ residual activity after 1 hour of incubation at $60^{\circ} \mathrm{C}$, and $50 \%$ residual activity at $70^{\circ} \mathrm{C}$ for $45 \mathrm{~min}$. Furthermore, Sharma et al. [14] reported that the lipase produced by Bacillus sp. RSJ-1 presented 90 and $70 \%$ residual activity after treatment at $50^{\circ} \mathrm{C}$ for 120 and $240 \mathrm{~min}$, respectively. Lipase obtained from Iftikhar et al. [46] showed that lipases retained $80 \%$ of its activity at $25-$ $30^{\circ} \mathrm{C}$ by wild and $100 \%$ of its activity at $20-50^{\circ} \mathrm{C}$ by mutant strain of $R$. oligosporus. By further increase in the incubation temperature, the activity of the enzyme was greatly inhibited.

Compared with the aforementioned enzymes, lipases obtained in this study through submerged fermentation had higher thermostability and may have applications in industrial processes that require high temperatures. Enzymatic processes that occur at higher temperatures have higher reaction rates [11]. It may be possible to use thermostable lipases in the synthesis of biopolymers, pharmaceuticals, agrochemicals, cosmetics, biodiesel, and aromas [47]. According to Diaz et al. [32] even for identical lipases produced by different methods of cultivation (submerged and solid-state), there may be thermostability differences caused by the binding of nonprotein compounds derived from the culture medium through noncovalent bonds to the lipases, changing their physical and chemical properties.

Enzyme thermostability may be affected by production conditions, such as the producer microorganism, the method of cultivation, and the medium used [10]. Thermostability is the result of the protein's amino acid sequence, which provides a more rigid conformation to the enzyme [11] through intramolecular interactions, with the internalization of hydrophobic residues and superficial exposure of hydrophilic residues [45]. Lipase thermostability may also be affected by the presence of compounds such as short-chain alcohols, metals, and ions as $\mathrm{Ca}^{+2}$ and $\mathrm{Mg}^{+2}$ which bind to the surface of enzymes whose binding sites are generally formed by negatively charged groups [48]. According to Iyer and Ananthanarayan [11] thermal stabilization of lipases may be caused by the presence of divalent ions, anions $\left(\mathrm{SO}_{4}{ }^{-2}>\right.$ $\left.\mathrm{Cl}^{-}>\mathrm{Br}^{-}>\mathrm{NO}_{3}^{-}>\mathrm{ClO}_{4}^{-}\right)$, or cations $\left(\mathrm{NH}_{4}^{+}>\right.$ $\left.\mathrm{K}^{+}>\mathrm{Na}^{+}>\mathrm{Mg}^{+2}>\mathrm{Ca}^{+2}>\mathrm{Ba}^{+2}\right) . \mathrm{Mg}^{+2}$ and $\mathrm{SO}_{4}{ }^{-2}$ were present in the lipase production culture medium, which, if not consumed by the fungus for growth and synthesis,

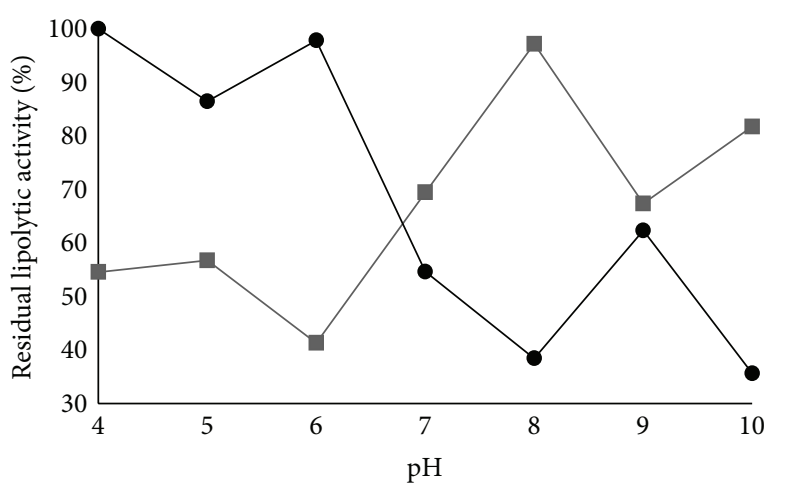

FIGURE 4: $\mathrm{pH}$ stability of lipases produced ( $)$ by Aspergillus flavus (strain O-8) through submerged fermentation and ( $\mathbf{\square})$ by Aspergillus niger (strain O-4) through solid-state fermentation.

remain soluble after the separation of cells, and become part of the lipolytic extract. That may explain the thermostability of the produced enzymes. However, if this enzyme extract containing lipases were purified for further use, causing the removal of these ions of the culture medium, the study of the stability of the purified protein would be needed.

3.3. $p H$ Stability. The $\mathrm{pH}$ stability of enzymatic extracts obtained through submerged and solid-state fermentation was determined according to Section 2.6 treating these extracts with different buffers for $24 \mathrm{~h}$ and after the enzymatic activity was determined using the optimized $\mathrm{pH}$ and temperature for the enzymes of each fermentation process (Section 2.4).

Figure 4 shows the residual lipolytic activity as a function of $\mathrm{pH}$ for the enzymes produced through solid-state and submerged fermentation. Lipases produced through submerged fermentation by Aspergillus flavus were stable at $\mathrm{pH}$ ranging from 3.5 to 6.5 for $24 \mathrm{~h}$, with residual activities greater than $80 \%$. At pH 7 to 10 there was a reduction in the stability of enzymes with residual activity of around 50\%.

Lipase produced through solid-state fermentation by Aspergillus niger had greater stability at $\mathrm{pH}$ greater than 7.0, with residual activity greater than $60 \%$. In acidic $\mathrm{pH}$ (4 to 6 ), the stability of the enzyme after $24 \mathrm{~h}$ was around $50 \%$. It was found that the enzyme showed optimal activity at acidic $\mathrm{pH}$ (6.0), while the highest stability was observed with alkaline $\mathrm{pH}$.

This behavior is similar to that reported by Mhetras et al. [45], who reported that lipases produced by Aspergillus niger NCIM 1207 were stable when $\mathrm{pH}$ was alkaline ( $\mathrm{pH} 8$ to 11) despite having had optimum activity at an acidic $\mathrm{pH}$. Sharma et al. [14] reported that the lipases produced by Bacillus sp. RSJ-1 had 84 and $82 \%$ residual activity, respectively, after $2 \mathrm{~h}$ at $\mathrm{pH} 8$ and 9 . The lipases produced by Candida sp. were stable at $\mathrm{pH}$ ranging from 7.5 to 8.5 for $15 \mathrm{~min}$ [27].

\section{Conclusion}

Lipase produced by the Aspergillus flavus (strain O-8) through submerged fermentation had maximum activities 
at $37^{\circ} \mathrm{C}$ and $\mathrm{pH} 7.2$. The thermal stability was $72 \%$ after $1 \mathrm{~h}$ of exposure to temperatures of 70 to $90^{\circ} \mathrm{C}$ and $\mathrm{pH}$ stability greater than $80 \%$ in acidic $\mathrm{pH}$, which are desirable traits for industrial application. On the other hand, lipases produced through solid-state fermentation with Aspergillus niger (O4) had optimum temperature and $\mathrm{pH}$ around $35^{\circ} \mathrm{C}$ and $\mathrm{pH}$ 6.0 and stability at room temperature $(63.6 \%$ and $26.8 \%$ of residual activity after $1 \mathrm{~h}$ of exposure to 50 and $60^{\circ} \mathrm{C}$, resp.), lower than that observed with enzymes obtained through submerged fermentation. The $\mathrm{pH}$ stability was higher in alkaline $\mathrm{pH}$, with residual activity greater than $60 \%$ after $24 \mathrm{~h}$ of exposure.

\section{Conflict of Interests}

The authors declare that there is no conflict of interests regarding the publication of this paper.

\section{Acknowledgments}

The authors thank CNPq for the financial support. They are very grateful to the researchers Fabio Rodrigo Duarte and Siu Mui Tsai, from Cena/USP, who carried out the identification of fungi used in this work.

\section{References}

[1] R. Sharma, Y. Chisti, and Y. C. Banerjee, "Production, purification, characterization, and applications of lipases," Biotechnology Advances, vol. 19, no. 8, pp. 627-662, 2001.

[2] N. Saisubramanian, N. G. Edwinoliver, N. Nandakumar, N. R. Kamini, and R. Puvanakrishnan, "Efficacy of lipase from Aspergillus niger as an additive in detergent formulations: a statistical approach," Journal of Industrial Microbiology and Biotechnology, vol. 33, no. 8, pp. 669-676, 2006.

[3] F. Hasan, A. A. Shah, and A. Hameed, "Industrial applications of microbial lipases," Enzyme and Microbial Technology, vol. 39, no. 2, pp. 235-251, 2006.

[4] C. Dupuis, C. Corre, and P. Boyaval, "Lipase and esterase activities of Propionibacterium freudenreichii subsp. freudenreichii," Applied and Environmental Microbiology, vol. 59, no. 12, pp. 4004-4009, 1993.

[5] R. Ben Salah, H. Ghamghui, N. Miled, H. Mejdoub, and Y. Gargouri, "Production of butyl acetate ester by lipase from novel strain of Rhizopus oryzae," Journal of Bioscience and Bioengineering, vol. 103, no. 4, pp. 368-372, 2007.

[6] M. V. Reshma, S. S. Saritha, C. Balachandran, and C. Arumughan, "Lipase catalyzed interesterification of palm stearin and rice bran oil blends for preparation of zero trans shortening with bioactive phytochemicals," Bioresource Technology, vol. 99, no. 11, pp. 5011-5019, 2008.

[7] D. Wang, Y. Xu, and T. Shan, "Effects of oils and oil-related substrates on the synthetic activity of membrane-bound lipase from Rhizopus chinensis and optimization of the lipase fermentation media," Biochemical Engineering Journal, vol. 41, no. 1, pp. 30-37, 2008.

[8] E. Y. Park, M. Sato, and S. Kojima, "Fatty acid methyl ester production using lipase-immobilizing silica particles with different particle sizes and different specific surface areas," Enzyme and Microbial Technology, vol. 39, no. 4, pp. 889-896, 2006.
[9] H. Treichel, D. de Oliveira, M. A. Mazutti, M. di Luccio, and J. V. Oliveira, "A review on microbial lipases production," Food and Bioprocess Technology, vol. 3, no. 2, pp. 182-196, 2010.

[10] R. R. Maldonado, Production, purification and characterization of lipase of Geotrichum candidum obtained from industrial media [dissertation], Universidade Estadual de Campinas-Unicamp, Campinas, Brazil, 2006.

[11] P. V. Iyer and L. Ananthanarayan, "Enzyme stability and stabilization-aqueous and non-aqueous environment," Process Biochemistry, vol. 43, no. 10, pp. 1019-1032, 2008.

[12] F. M. Gomes, A. V. de Paula, G. S. Silva, and H. F. de Castro, "Determinação das propriedades catalíticas em meio aquoso e orgânico da lipase de Candida rugosa imobilizada em celulignina quimicamente modificada por carbonildiimidazol," Química Nova, vol. 29, no. 4, pp. 710-718, 2006.

[13] E. Rajakumara, P. Acharya, S. Ahmad, R. Sankaranaryanan, and N. M. Rao, "Structural basis for the remarkable stability of Bacillus subtilis lipase (Lip A) at low pH," Biochimica et Biophysica Acta, vol. 1784, no. 2, pp. 302-311, 2008.

[14] R. Sharma, S. K. Soni, R. M. Vohra, L. K. Gupta, and J. K. Gupta, "Purification and characterisation of a thermostable alkaline lipase from a new thermophilic Bacillus sp. RSJ-1," Process Biochemistry, vol. 37, no. 10, pp. 1075-1084, 2002.

[15] A. Glogauer, V. P. Martini, H. Faoro et al., "Identification and characterization of a new true lipase isolated through metagenomic approach," Microbial Cell Factories, vol. 10, article $54,2011$.

[16] L. M. Colla, A. L. Primaz, S. Benedetti et al., "Selection of lipaseproducing microorganisms through submerged fermentation," Zeitschrift für Naturforschung, vol. 65, no. 7-8, pp. 483-488, 2010.

[17] L. M. Colla, K. Rezzadori, S. K. Câmara et al., "A solid-state bioprocess for selecting lipase-producing filamentous fungi," Zeitschrift für Naturforschung, vol. 64, no. 1-2, pp. 131-137, 2009.

[18] A. Smaniotto, A. Skovronski, E. Rigo et al., "“Synthetic lipase” production from a newly isolated Sporidiobolus pararoseus strain by submerged fermentation," Brazilian Journal of Microbiology, vol. 43, no. 4, pp. 1490-1498, 2012.

[19] L. M. Colla, Biotechnological optimization of lipases production and its correlation with biossurfactantes production [Ph.D. thesis], Federal University of Rio Grande-FURG, Rio Grande, RS, Brazil, 2009.

[20] T. E. Bertolin, J. A. V. Costa, and G. D. L. Pasquali, "Glucoamylase production in batch and Fed-batch solid state fermentation: effect of maltose or starch addition," Journal of Microbiology and Biotechnology, vol. 11, no. 1, pp. 13-16, 2001.

[21] J. F. M. Burkert, F. Maugeri, and M. I. Rodrigues, “Optimization of extracellular lipase production by Geotrichum sp. using factorial design," Bioresource Technology, vol. 91, no. 1, pp. 7784,2004

[22] W. Schmidell, E. Aquarone, W. Borzani et al., Biotecnologia Industrial, vol. 2, Editora Edgard Blücher, São Paulo, Brazil, 2001.

[23] M. Raimbault, "General and microbiological aspects of solid substrate fermentation," Electronic Journal of Biotechnology, vol. 1, no. 13, pp. 174-188, 1998.

[24] R. V. Muralidhar, R. R. Chirumamila, R. Marchant, and P. Nigam, "A response surface approach for the comparison of lipase production by Candida cylindracea using two different carbon sources," Biochemical Engineering Journal, vol. 9, no. 1, pp. 17-23, 2001. 
[25] Y. Teng and Y. Xu, "Culture condition improvement for wholecell lipase production in submerged fermentation by Rhizopus chinensis using statistical method," Bioresource Technology, vol. 99, no. 9, pp. 3900-3907, 2008.

[26] R. Kaushik, S. Saran, J. Isar, and R. K. Saxena, "Statistical optimization of medium components and growth conditions by response surface methodology to enhance lipase production by Aspergillus carneus," Journal of Molecular Catalysis B: Enzymatic, vol. 40, no. 3-4, pp. 121-126, 2006.

[27] D. Fu, M. Yu, T. Tan, and X. Zhou, "Separation, characterization and catalytic properties of Lip2 isoforms from Candida sp. 99125," Journal of Molecular Catalysis B: Enzymatic, vol. 56, no. 2-3, pp. 115-121, 2009.

[28] A. M. Baron, V. M. Z. Turra, D. A. Mitchell et al., "Produção e caracterização de lipases de Penicillium corylophilum IOC 4211," in Proceedings of 15th National Symposium of Fermentations, Recife, Brazil, 2005.

[29] D. M. Freire, P. M. Gomes, E. P. S. Bon et al., "Lipase production by a new promissing strain Penicillium restrictum," Revista de Microbiologia, vol. 28, no. 1, pp. 6-12, 1997.

[30] S. Benjamin and A. Pandey, "Isolation and characterization of three distinct forms of lipases from candida rugosa produced in solid state fermentation," Brazilian Archives of Biology and Technology, vol. 44, no. 2, pp. 213-221, 2001.

[31] G. M. Pastore, V. S. R. Costa, and M. G. B. Koblitz, "Purificação parcial e caracterização bioquímica de lipase extracelular produzida por nova linhagem de Rhizopus sp," Food Science and Technology, vol. 23, no. 2, pp. 135-140, 2003.

[32] J. C. M. Diaz, J. A. Rodríguez, S. Roussos et al., "Lipase from the thermotolerant fungus Rhizopus homothallicus is more thermostable when produced using solid state fermentation than liquid fermentation procedures," Enzyme and Microbial Technology, vol. 39, no. 5, pp. 1042-1050, 2006.

[33] J. A. Santos, C. O. M. Amaral, T. A. S. Araújo et al., "Produção, extração e caracterização parcial de lipase extracelular de Trichosporon sp pelo sistema de duas fases aquosas PEG-sais fosfatos," in Proceedings of the National Symposium of Fermentations XV, Recife, Brazil, 2005.

[34] P. Lotrakul and S. Dharmsthiti, "Purification and characterization of lipase from Aeromonas sobria LP004," Journal of Biotechnology, vol. 54, no. 2, pp. 113-120, 1997.

[35] J.-J. Shangguan, Y.-Q. Liu, F.-J. Wang et al., "Expression and characterization of a novel lipase from Aspergillus fumigatus with high specific activity," Applied Biochemistry and Biotechnology, vol. 165, no. 3-4, pp. 949-962, 2011.

[36] V. M. G. Lima, D. A. Mitchell, and N. Krieger, "Caracterização cinética e bioquímica da lipase de Bacillus megaterium," in Proceedings of the 15th National Symposium of Fermentations, Recife, Brazil, 2005.

[37] P. Atkins and L. Jones, Princípios de Química: Questionando a Vida Moderna e o Meio Ambiente, Editora Bookman, Porto Alegre, Brazil, 2001.

[38] O. R. Fennema, Introduccion a La Ciência de los Alimentos, Reverte, Barcelona, Spain, 2000.

[39] C. N. A. Razak, A. B. Salleh, R. Musani, M. Y. Samad, and M. Basri, "Some characteristics of lipases from thermophilic fungi isolated from palm oil mill effluent," Journal of Molecular Catalysis B: Enzymatic, vol. 3, no. 1-4, pp. 153-159, 1997.

[40] E. H. Ghanem, H. A. Al-Sayed, and K. M. Saleh, "An alkalophilic thermostable lipase produced by a new isolate of Bacillus alcalophilus," World Journal of Microbiology and Biotechnology, vol. 16, no. 5, pp. 459-464, 2000.
[41] N. Nawani, N. S. Dosanjh, and J. Kaur, "A novel thermostable lipase from a thermophilic Bacillus sp.: characterization and esterification studies," Biotechnology Letters, vol. 20, no. 10, pp. 997-1000, 1998.

[42] N. Kulkarni and R. V. Gadre, "Production and properties of an alkaline, thermophilic lipase from Pseudomonas fluorescens NS2W,' Journal of Industrial Microbiology and Biotechnology, vol. 28, no. 6, pp. 344-348, 2002.

[43] G. Ginalska, R. Bancerz, and T. Korniłłowicz-Kowalska, "A thermostable lipase produced by a newly isolates Geotrichumlike strain, R59," Journal of Industrial Microbiology and Biotechnology, vol. 31, no. 4, pp. 177-182, 2004.

[44] C. H. Shu, C. J. Xu, and G. C. Lin, "Purification and partial characterization of a lipase from Antrodia cinnamomea," Process Biochemistry, vol. 41, no. 3, pp. 734-738, 2006.

[45] N. C. Mhetras, K. B. Bastawde, and D. V. Gokhale, "Purification and characterization of acidic lipase from Aspergillus niger NCIM 1207," Bioresource Technology, vol. 100, no. 3, pp. 14861490, 2009.

[46] T. Iftikhar, M. Niaz, R. Jabeen, and I. U. Haq, "Purification and characterization of extracellular lipases," Pakistan Journal of Botany, vol. 43, no. 3, pp. 1541-1545, 2011.

[47] H. Horchani, H. Mosbah, N. B. Salem, Y. Gargouri, and A. Sayari, "Biochemical and molecular characterisation of a thermoactive, alkaline and detergent-stable lipase from a newly isolated Staphylococcus aureus strain," Journal of Molecular Catalysis B: Enzymatic, vol. 56, no. 4, pp. 237-245, 2009.

[48] K. Chakraborty and R. P. Raj, "An extra-cellular alkaline metallolipase from Bacillus licheniformisMTCC 6824: purification and biochemical characterization," Food Chemistry, vol. 109, no. 4, pp. 727-736, 2008. 

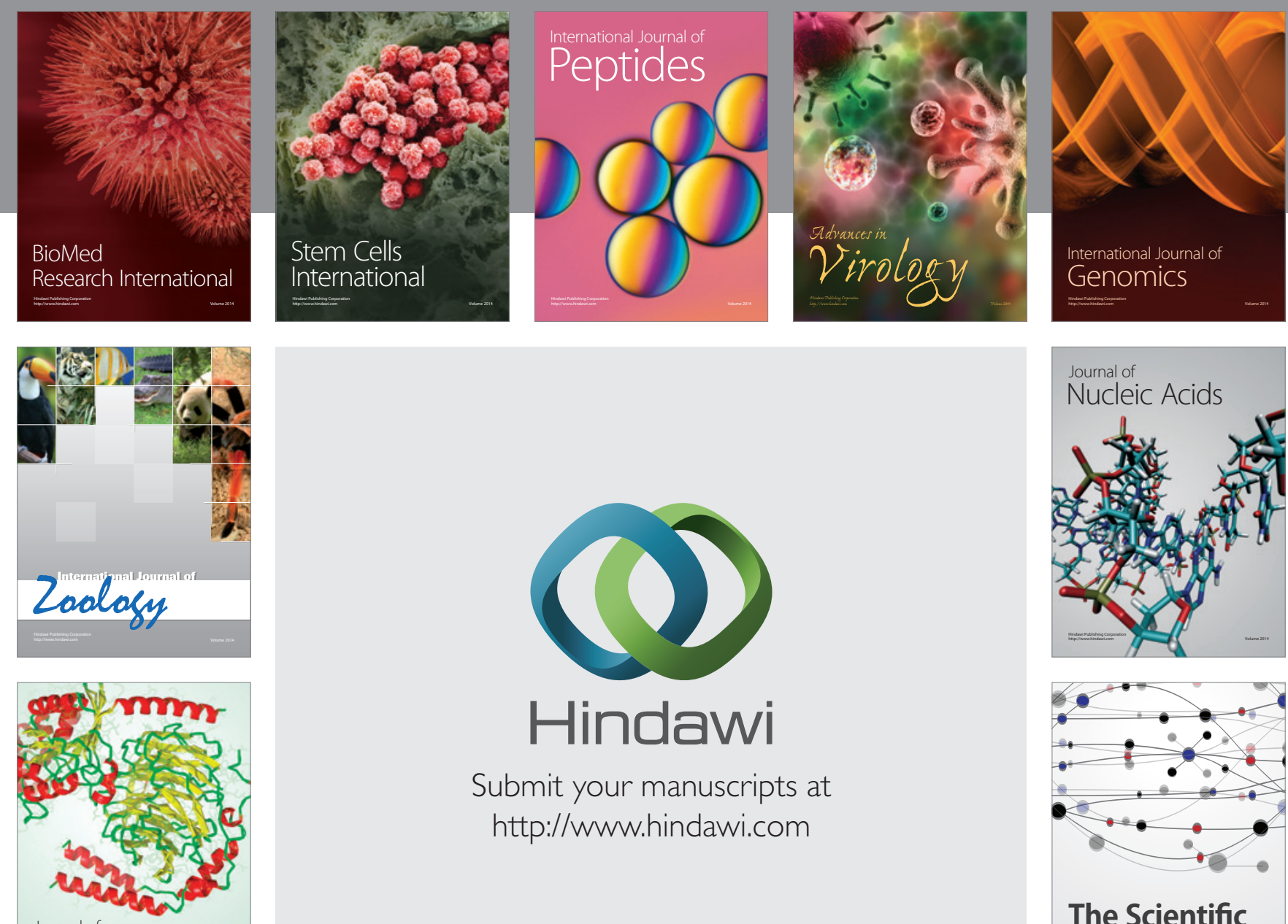

Submit your manuscripts at

http://www.hindawi.com

Journal of
Signal Transduction
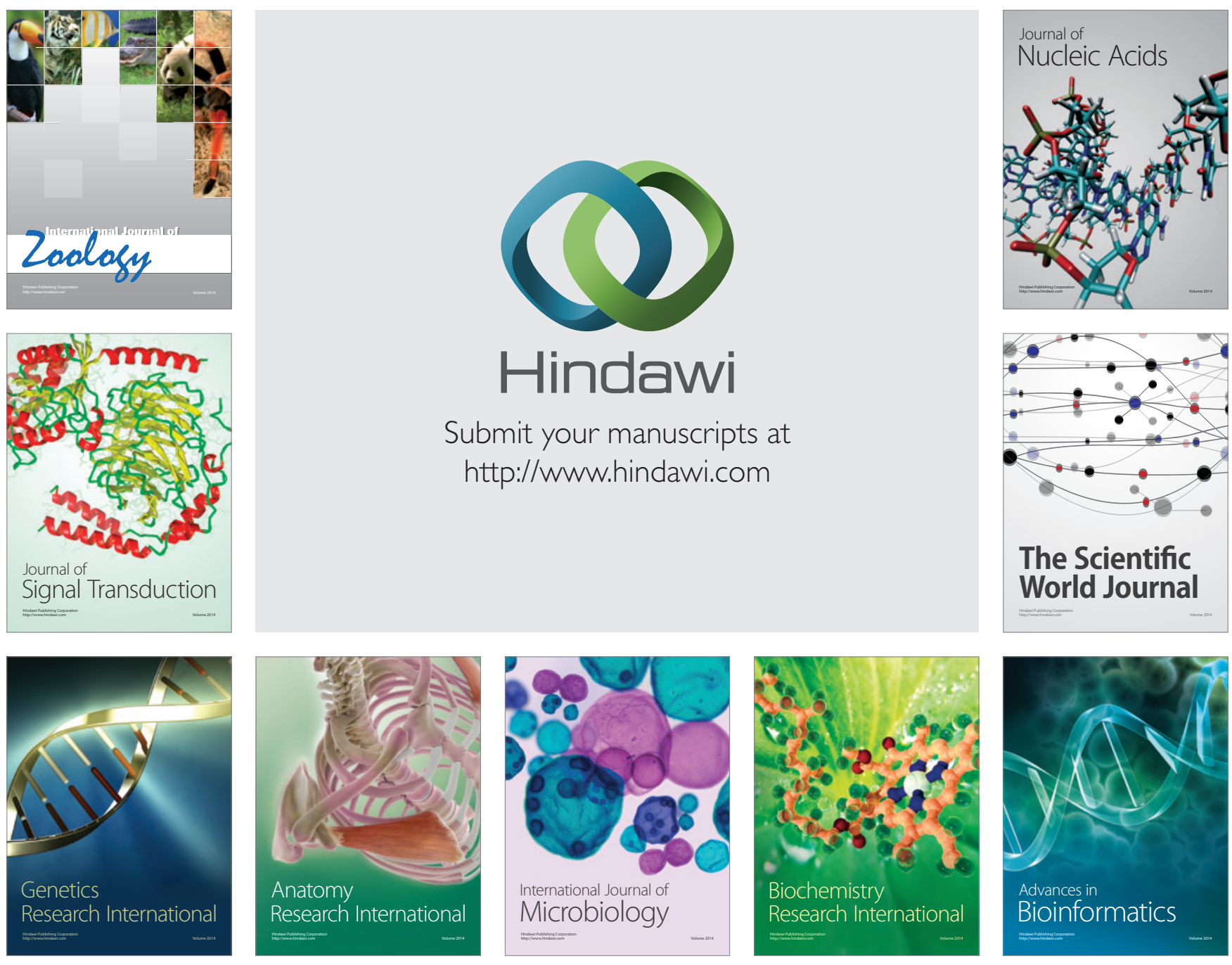

The Scientific World Journal
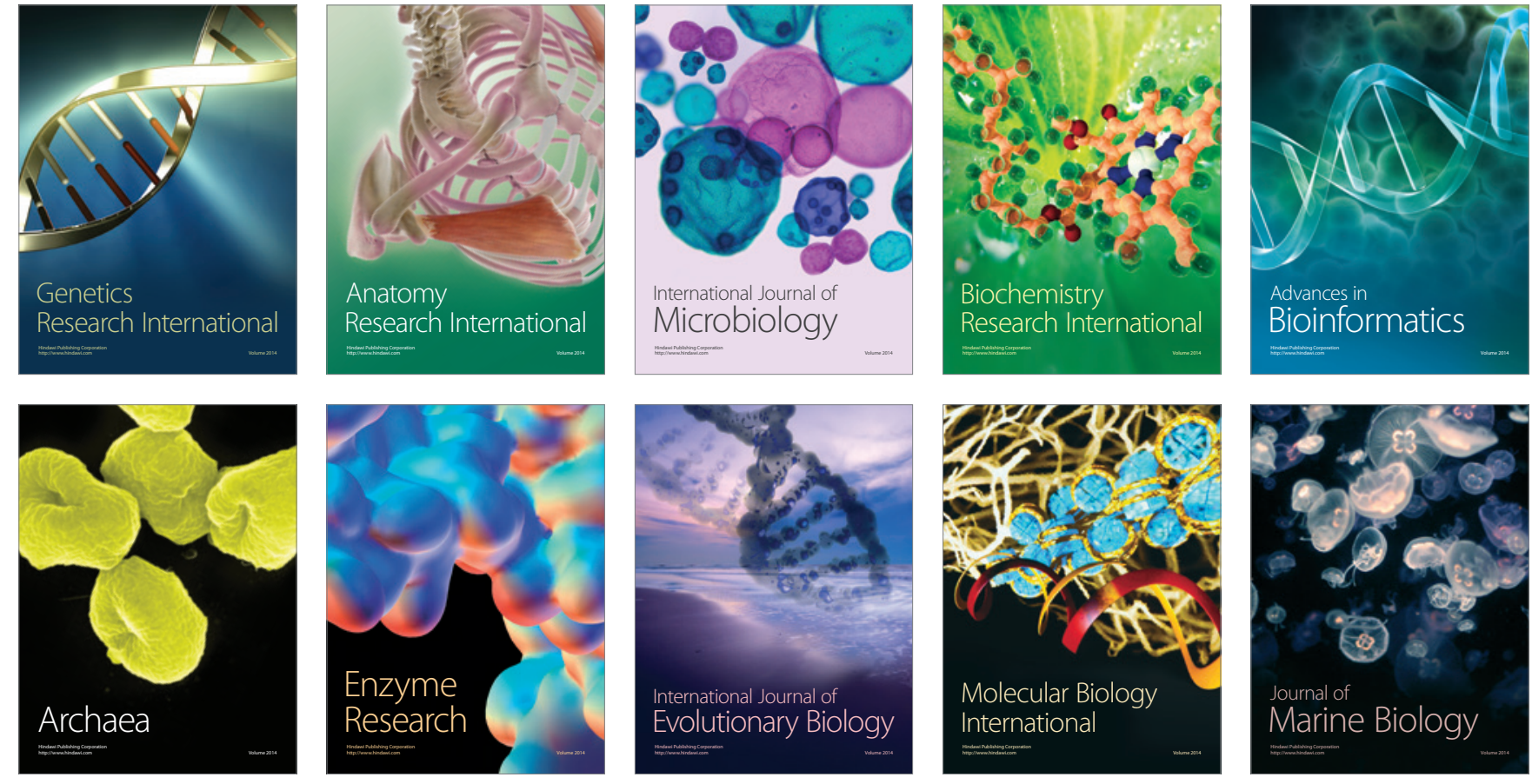